\title{
TRENDS AND REGIONAL DIFFERENCES IN BREASTFEEDING IN GERMANY FROM 1871 TO 1937*
}

\author{
Hallie J. Kintner**
}

\begin{abstract}
This article describes trends and regional differences in breastfeeding within Germany from 1870 to 1937. Sharp regional differences in both the incidence and duration of breastfeeding are present around 1910. There is a complex pattern of trends in infant-feeding practices. Breastfeeding declined in urban areas between the late nineteenth century and the first World War. A strong nation wide resurgence in the incidence of breastfeeding occurred between the two world wars, accompanied by a decline in the average duration of breastfeeding. By 1937, the formerly great regional differences in breastfeeding had nearly disappeared. The article also discusses social, economic, cultural, and historical variables affecting infant-feeding practices, including local breastfeeding customs, a national infant welfare campaign, and allowances to nursing mothers.
\end{abstract}

\section{Introduction}

Recent evidence of the profound demographic effects of breastfeeding demonstrates the importance of documenting infant-feeding practices among historical populations. This paper describes regional differences in maternal breastfeeding and changes over time in the major method of feeding infants in Germany

*The author is grateful to the German Academic Exchange Service for funding a fellowship for data collection, to John Knodel, Allison McIntosh, and the reviewers for their comments on an earlier version of this paper, which was presented at the 1982 annual meeting of the American Public Health Association, Montreal, Canada, November 14-18, 1982.

${ }^{* *}$ Hallie J. Kintner (Societal Analysis Department, General Motors Research Laboratories, Warren, MI 48090-9055) did the research on which this article is based in connection with her dissertation, The Determinants of Infant Mortality in Germany from 1871 to 1933, Department of Sociology, University of Michigan, 1982. during the late nineteenth and early twentieth centuries. It also examines the influence of social, economic, and cultural factors on breastfeeding patterns.

Interest in studying the effects of breastfeeding on fertility and on infant mortality has grown in the past few years, leading to a better understanding of their biological basis. Prolonged breastfeeding reduces fertility by extending the period of postpartum amenorrhea (van Ginneken, 1974; Thomson, Hytten, and Black, 1975), perhaps through increased production of prolactin and other hormones in response to the infant's sucking (Tyson and Perez, 1978). The substantial survival advantage of breastfed infants over artificially fed infants has been noted in historical European and American populations as well as in contemporary, less-developed countries (see, for instance, Knodel, 1977; Wray, 1978; Woodbury, 1925; and Cunningham, 1981). Breast milk is not only nutritionally ideal 
for the growing child but it also transmits needed immunities from the mother (Chandra, 1978) and is clean-a particularly important advantage in areas where sanitary conditions are poor. The survival advantage of breastfed children appears to have declined over time, probably because hygienic conditions and the nutritional adequacy of artificial food improved (Wray, 1978).

The demographic consequences of maternal breastfeeding have been quantified and appear large. Where breastfeeding continues for one to two years, lactational amenorrhea (the prevention of ovulation by lactation) persists for 60 to 70 percent of the duration of breastfeeding. Lactation has the greatest fertility inhibiting effect in populations in which fertility levels are high (Bongaarts and Potter, 1983). According to historical evidence, deaths before age 1 ranged from 10 to 30 percent higher among artificially fed infants than among the breastfed (Knodel, 1977). The magnitude of the survival advantage of breastfed infants, however, is in doubt because of methodological flaws in some studies (Millman, 1982).

Since the demographic consequences of infant-feeding practices are considerable, it is important to document the level of breastfeeding in populations. Historical research indicates that, aside from a few exceptions, prolonged breastfeeding was the predominant method of feeding infants in Europe and the United States until the 1930s (Vahlquist, 1975; Meyer, 1968). Though breastfeeding was common in most of Europe around the turn of the century (Bluhm, 1912b), other methods prevailed in some areas. Wetnursing was very popular in France (Sussman, 1977) and in parts of Belgium (Bluhm, 1912b).

Geographical variation in infantfeeding practices was pronounced in some areas of Europe. For instance, in France around 1900 , breastfeeding was common in the south, while north of the Loire infants received animal milk (Rollet, 1978). The unusual custom of hand-feeding infants with meal paps was found in parts of central Europe, including southern Germany (Knodel and van de Walle, 1967).

Infant-feeding practices also differed over time. Wet-nursing in France dropped sharply during World War I and never regained its prewar popularity (Sussman, 1977). Infant formulas and other products became more widely used in the 1930 s (Vahlquist, 1975).

Several social, economic, and cultural factors influence infant-feeding practices. Though the study of the effects of these factors has concentrated on contemporary third world countries, they may operate similarly in historical European populations. Breastfeeding is associated with rural residence, low income, low mother's education, low contraceptive use, and low female labor force participation in the nonagricultural sectors (Knodel and Debavalya, 1980; Jain and Bongaarts, 1981; Millman, 1982). Female labor force participation, urban residence, and occupation had similar effects in France around 1900 (Sussman, 1977). Other factors may also have influenced European breastfeeding patterns. For instance, sharp regional differences within European countries suggest that infantfeeding practices were based at least partly on local custom. Such cultural factors, however, may not completely explain these geographical patterns. Economic conditions, including the extent of female labor force participation and the geographical distribution of dairy farming, were associated with maternal breastfeeding practices in France around 1900 (Rollet, 1978). The prevalence of illegitimacy may also be negatively associated with the incidence and duration of breast- 
feeding. Illegitimate infants were frequently not breastfed because they tended to be cared for by institutions or other persons while their mothers worked (Seutemann, 1913). Illegitimate infants were proportionately overrepresented among children who were wet-nursed in France around the turn of the century (Sussman, 1977). The price of alternative infant foods, such as animal milk, may also have influenced how parents fed their children.

The first part of this paper describes regional breastfeeding patterns in Imperial Germany and the social, economic, and cultural factors associated with them. The second section documents trends in infant-feeding practices from 1871 to 1937, while the third part of this paper discusses factors that may have contributed to the increased incidence of breastfeeding.

\section{Sources of Data on Breastfeeding}

During the late nineteenth century, public health officials in Germany became concerned about very high infant mortality rates and began to collect descriptive and statistical information on breastfeeding. In contrast to France, which established a nationwide registration system with standard data collection procedures (Sussman, 1977), most of the German studies concerned local areas and used a variety of data collection techniques (see Kintner, 1982 for additional information on data sources).

The study of regional breastfeeding practices in 1910 is based on the administrative units used in Knodel's monograph on fertility in Germany (Knodel, 1974). They are a mixture of middle-level political units (Regierungsbezirke) for larger provinces, including Prussia, Bavaria, Baden, Saxony, and Hessen, and smaller units, such as Mecklenburg, Anhalt, and Lippe. Information on the incidence and duration of breastfeeding in these areas was compiled from several different studies. The data sources include surveys of Prussian district doctors in 1908-1909 (Kaup, 1910), and surveys of Bavarian and Hessen mothers who brought their infants to be vaccinated at public vaccination centers (Groth and Hahn, 1910; Hesse, 1909). Other sources were reports from midwives in Baden of the proportion of women who breastfed their own children in the first one or two weeks after confinement (Baden, Statistical Office, 1883-1913), a review article (Bluhm, 1912b), and a study based on both parental reports of how school children were fed and retrospective reports of military recruits (Roese, 1905). No information on the duration of breastfeeding is available for several of these sources. It is difficult to evaluate the quality of some sources because data collection procedures are not fully described.

For some administrative areas the information on breastfeeding is provided for subdivisions of the areas only. In these cases values for the entire area were calculated as the sums of the proportion of infants breastfed in the subdivisions weighted by the proportion of live births occurring in the respective subdivisions.

Trends in breastfeeding are documented in several areas of Germany. Many of the sources of information on breastfeeding trends are high quality in terms of the representativeness of the sample and the comparability of data from different years. For instance, the erosion of breastfeeding in Berlin from 1880 to 1910 is documented by census data (Berlin, Statistical Office, various volumes). Parents were asked how they fed their infant at the time of the census. The same question was used for each of the censuses, so the data from different years are comparable. Similarly, the data on Baden during the period 1873-1934 are 
taken from one source, midwives' reports, and all or nearly all concern infants born during these years (Günther, 1937). These data refer to the percentage of infants surviving to age nine days who were breastfed. Information about the duration of breastfeeding was not collected in Berlin and Baden.

In contrast to the data sources for Berlin and Baden, information on Munich during $1861-1933$ is taken from several studies, which were based on different samples and which used different data collection procedures. Data for the periods 1861-1869, 1870-1878, 1879-1886 come from a study of the Munich child clinic (Escherich, 1887). Data for 1901-1903 and 1904 are from Groth and Hahn's survey of public vaccination centers (Groth and Hahn, 1910). Data for 1910 are taken from the Munich census (Morgenroth, 1913). Data for the 1915-1919 are from a study of Munich infant welfare centers (Hecker, 1920, 1923). Data on the length of breastfeeding were collected by social workers who frequently made home visits. The data for 1924-1933 are from a survey of public vaccination centers (Seidlmayer, 1937). Although only one of these studies concerns the entire population of Munich, the others refer to infants from the same social stratum and therefore are fairly comparable.

The nationwide resurgence in breastfeeding is documented by comparing regional breastfeeding practices around 1910 to those in 1937. The source of the 1937 data is a large national survey conducted by the infant welfare centers (Pohlen, 1937, 1939; Thieme, 1940; Germany, Reichsministerium, 1937). Although this survey concerns only infants brought to infant welfare centers for medical examinations or consultations or those visited at home by welfare workers, it includes nearly half of the live births in
Germany in 1937. It excludes those attended by private physicians as well as those in which the infants died shortly after birth.

The 1937 data refer to larger geopolitical units (provinces) than the 1910 data do (administrative areas). Information on the indices of breastfeeding in 1910 for these larger units was derived by taking weighted averages of the values for the smaller administrative areas, where the weights are the proportion of total live births in the larger unit which occurred in each administrative area.

The data from the 1910 and 1937 data sets are fairly comparable in terms of the percentage of infants ever breastfed. Both may overestimate the incidence of breastfeeding because they exclude infants dying shortly after birth who were never breastfed. They probably overrepresent births from the poorest classes and from the largest cities, where most of the infant welfare centers were located.

The data on the average duration of breastfeeding in these data sets are less comparable because many of the sources for the 1910 data set did not specify whether infants on mixed feeding regimes were included in the calculations of the average duration of breastfeeding and how their duration was estimated if they were included. The 1937 study may overestimate the average duration of breastfeeding because infants fed both breast milk and-animal milk were considered to be breastfed (Thieme, 1940).

The preceding review of the sources of information on breastfeeding in Germany suggests that most of the samples are representative of at least a large segment of the population. Also, the data sets used to examine trends are, for the most part, comparable for different time points. They are therefore more likely to reflect actual trends in breastfeeding practices rather than differences among data sets. 


\section{Regional Breastfeeding Patterns in 1910}

The existence of sharp regional differences in breastfeeding, fertility, and infant mortality in portions of Germany during the early twentieth century has been described previously (Knodel and van de Walle, 1967). This study extends prior research by documenting breastfeeding patterns in northern Germany.

The incidence of maternal breastfeeding in Germany at this time was fairly high. On average, nearly 75 percent of the infants in an administrative area received some breast milk during around 1910 (see Table 1). Sharp regional differences in the incidence of breastfeeding are evident in Map 1. In contrast to southeastern Germany, where most infants were never breastfed, the incidence of breastfeeding was quite high in northwestern Germany, aside from cities such as Berlin, Hamburg, and Bremen. The practice of never breastfeeding appears to be confined to southern Bavaria, the neighboring province of Donaukreis in Württemberg and to parts of the Kingdom of Saxony, as
Knodel and van de Walle (1967) reported earlier.

Although less data are available on regional variation in the average duration of breastfeeding, the same patterns are present (Map 2). Infants were breastfed for the longest time in northwestern Germany. Early weaning was most common in southeastern Germany (Bavaria and Württemberg) and in Sachsen. The average period of breastfeeding in 34 administrative areas around 1910 was 5.8 months (Table 1), twice as long as the 2.9 month average in 94 Bavarian districts.

\section{Correlates of Regional Breastfeeding Patterns}

The unusual infant-feeding practice of Nichtstillen (never breastfeeding) was a long-standing tradition in central Europe, including parts of southern Germany, Bohemia, the Austrian Tyrol (Knodel and van de Walle, 1967) and Switzerland (Bluhm, 1912b). By the fifteenth century infants in southern Bavaria were fed meal

MAP 1. PERCENTAGE OF INFANTS EVER BREASTFED, 56 GERMAN ADMINISTRATIVE AREAS, 1903-1909.

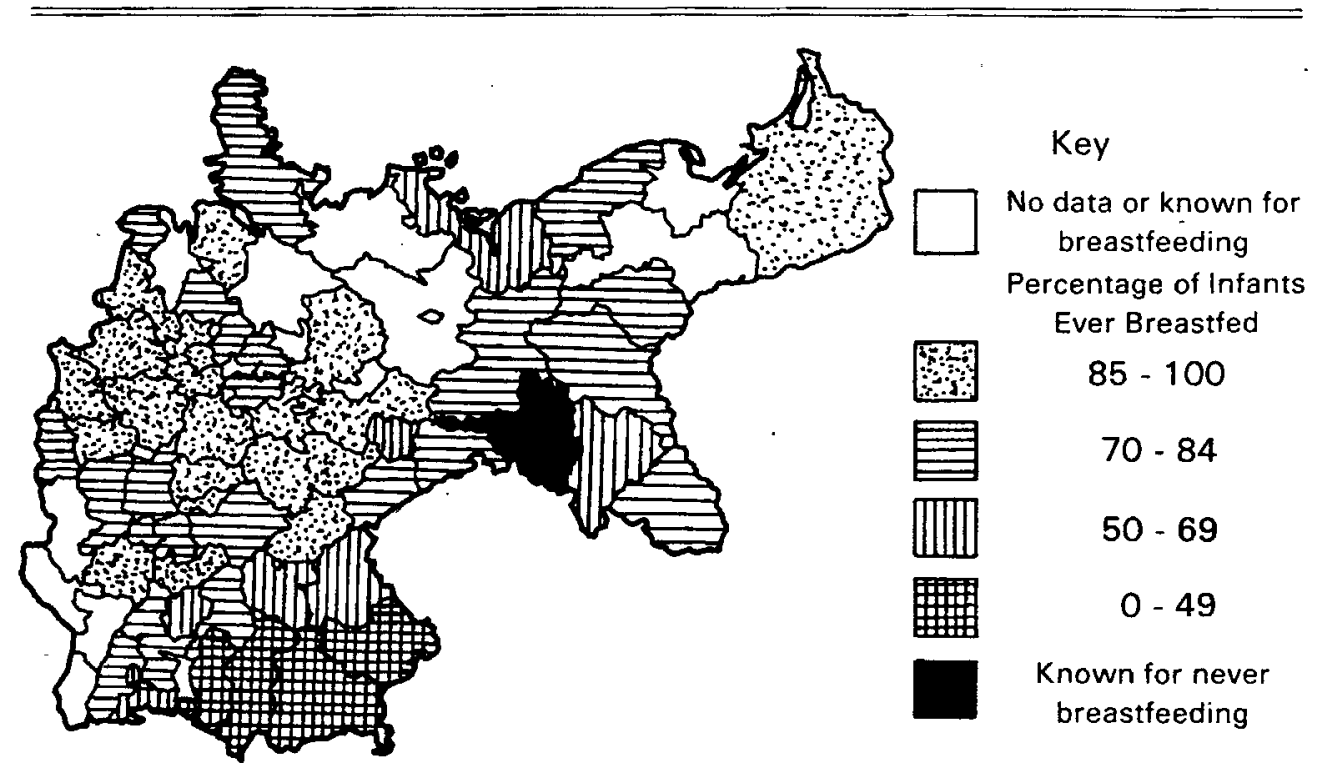


MAP 2. AVERAGE DURATION OF BREASTFEEDING, 35 GERMAN ADMINISTRATIVE AREAS, 1903-1909.

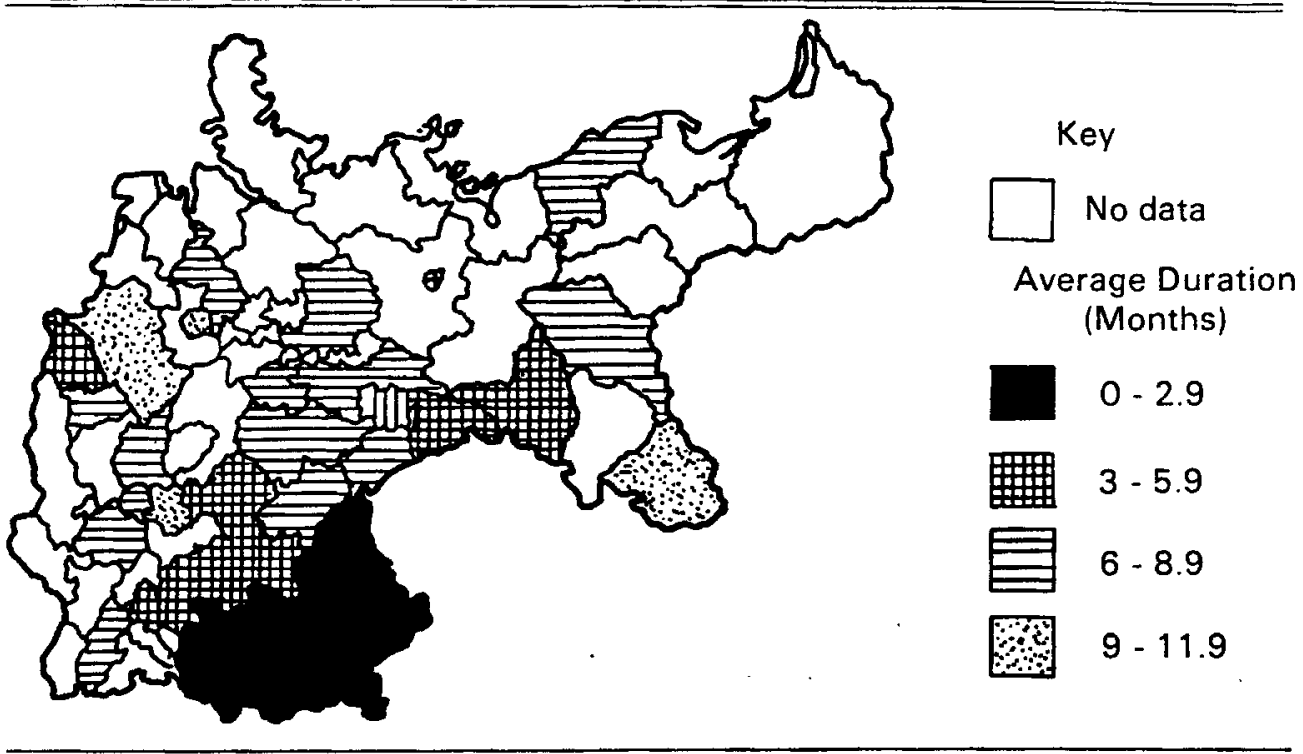

pap (Mehlbrei) instead of being breastfed (Metlinger, 1473, cited in Biedert, 1905). Exceptions to this practice were subject to severe social sanctions, including ridicule from neighbors and threats from husbands (Bernheim, 1888). Further evidence that this practice was a long-standing tradition comes from the scripts of the Passion and Christmas plays of farmers in Oberbayern. Instead of breastfeeding the Christ child, Mary cooked him a meal pap' (Mueller, 1912).

Investigations of this phenomenon have failed to find any one particular factor responsible for its origin. Rather, Mueller concludes that it may have had several causes, including maternal neglect, physical inability, discouragement from doctors, obesity, alcoholism, and tight corsets (Mueller, 1912). His finding that in areas in which never breastfeeding was prevalent the local costume included a tightly fitted corset suggests that the practice may have been culturally determined with a possible physiological mechanism. Such deficient functioning of the milk glands was speculated to result from alcoholism or from a genetically transmitted inability (Bluhm, 1912a).
Several alternatives to maternal breastfeeding were available. One of the most popular infant foods was meal pap, a mixture of flour, water, and raw milk, which was cooked until it was so thick that a spoon would stand up in it (Anonymous, 1868). The meal pap was prepared in large quantities and was used after it had gone sour. Other infant foods included oat groats, barley groats, zwieback soup, chicory coffee, milk with zwieback and sugar, bouillon, a pap made from potatoes, black bread, and sometimes also cheese, and rice (Peiper, 1966; Teuteberg and Bernhard, 1978; Fischer, 1933). Unsweetened, undiluted cow's milk was rarely given to infants (Fischer, 1933). Commercially prepared infant foods, such as Nestle's Kindermehl and Leibigsche's Suppe, although attempts to duplicate the composition of human breast milk, typically contained less protein and more sugar.

The next section examines the association between some social and economic factors and regional breastfeeding pat- 
terns. A few other factors which may influence breastfeeding, such as fertility and family income, could not be examined because no information is available. The variables and the sources of data on them are described before the results are presented.

For this analysis the $1903 / 1910$ breastfeeding data are used in conjunction with data on social and economic factors. Much of this additional data comes from vital statistics and the 1907 census of occupations and was collected by John Knodel (Knodel, 1974). Most indicators were chosen by their availability. Female labor force participation is represented by the proportion of women over age 14 who were employed in the secondary (manufacturing, mining, and construction) and tertiary (trade, transportation, and communication) sectors. Illegitimacy is indicated by the proportion of total live births that are illegitimate. The price of alternative infant foods is represented by the price of a liter of milk in 1910. The information on the price of milk was collected from the statistical publications of several German states. ${ }^{2}$ This variable is not the best measure of alternative infant foods since, as was noted earlier, ordinary cow's milk was infrequently given to infants. However, milk was used in the meal pap and its price is probably closely associated with that of other foods.

${ }^{2}$ Data on milk prices were obtained for the respective administrative areas from the following: Preussische Statistik, vol. 227, p. 75; Zeitschrift des Bayerischen Statistischen Landesamtes, vol. 43, p. 298; Statistisches Jahrbuch für das Königreich Sachsen 40 (1912), p. 156; Statistisches Jahrbuch für das Grossherzogtum Baden, vol. 39, 1912, p. 185; Mitteilungen der Hessischen Centralstelle, no. 901; Jahrbuch für Bremische Statistik, 1912, vol. 2, p. 148. Data for Hamburg were taken from Jahrbuch deutscher Städte, vol. 20, p. 204 and were adjusted to 1910 using the national price index presented in Bevolkerung und Wirtschaft, 1872-1972, p. 250. Data for Thüringen come from Statistik des Herzogtums Sachsen-Meiningen, 1910, p. 397.
Table 1 presents means and standard deviations for each variable in this data set as well as the zero order correlation matrix. Breastfeeding patterns are measured by three indicators. The incidence of breastfeeding is represented by the percentage of infants ever breastfed. The duration of breastfeeding is indicated by the average duration of breastfeeding of all infants (including those never breastfed) as well as by the average duration of breastfeeding of only those infants who were breastfed. As expected, all three of these indicators are negatively correlated to illegitimacy and female labor force participation. These correlations are statistically significant. Contrary to expectations, all breastfeeding measures are unrelated to the price of milk.

This section has provided evidence that the geographical pattern of breastfeeding reflects the influence of several factors. Regional breastfeeding practices are closely related to geographical variation in female labor force participation and il. legitimacy. They are also related to local customs, though this effect could not be analyzed statistically. They are unrelated to milk price.

\section{Declining Breastfeeding in Berlin, 1885-1910}

Berlin provides a well-documented example of a drop in breastfeeding during the late nineteenth century. Table 2 suggests that Berlin was an area where infants were traditionally breastfed and that it experienced a serious decline in breastfeeding. The top panel of this table presents the percentage of infants fed various kinds of foods at the time of the census. The percentage of infants receiving breast milk fell sharply from 55 percent in 1885 to 30 percent in 1910 . The popularity of animal milk rose as the incidence of breastfeeding fell. Wet-nursing was not a major method of infant feeding. The steady increase in 
TABLE 1. BREASTFEEDING AND SOCIAL FACTORS IN GERMANY, 1910.

\begin{tabular}{|c|c|c|c|c|c|c|c|c|}
\hline Variable & PBFa & $A_{V D R A}^{b}$ & $A V D R B C$ & FLFPd & ILEG $^{e}$ & MLKPRCEf & Mean & Standard Deviation \\
\hline PBFa & 1.00 & & & & & & 74.0 & 16.0 \\
\hline AVDRA $^{b}$ & .78 & 1.00 & & & & & 5.8 & 2.6 \\
\hline AVDRBC & .41 & .85 & 1.00 & & & & 7.9 & 2.9 \\
\hline FLFPd & -.34 & -.30 & -.09 & 1.00 & & & .1 & .1 \\
\hline ILEG $^{\mathrm{e}}$ & -.57 & -.48 & -.17 & .51 & 1.00 & & 8.9 & 4.2 \\
\hline MLKPRCE ${ }^{f}$ & .13 & .21 & .28 & .36 & .02 & 1.00 & 18.8 & 1.9 \\
\hline
\end{tabular}

NotEs: $\mathrm{N}=34$ for correlations involving AVDRA, 33 for those with AVDRB, and 52 otherwise. apercentage of live births ever breastfed.

${ }^{b}$ Average duration of breastfeeding of all infants, including those never breastfed. cAverage duration of breastfeeding of only those infants who were breastfed. dpercentage of women age 14 and over employed in secondary and tertiary sectors. epercentage of total live births that are illegitimate.

Price of a liter of milk.

the percentage of infants fed a mixture of breast and animal milk from 1885 to 1900 suggests that initially the movement away from breast milk involved not a direct switch to animal milk but first a change to a mixed regime. The sharp reduction between 1900 and 1905 in the incidence of mixed feeding and the corresponding and nearly equal increase in the use of animal milk in the face of no change in the percentage breastfed suggests that the initial reasons for mixing were suddenly viewed as invalid or that artificial foods suddenly became more readily available, perhaps with the establishment of milk kitchens, which provided pasteurized milk at minimal cost (Wuertz, 1912).

The second and third panels of Table 2 further document the decline in breastfeeding. Panel $B$ refers to infants who received only breastmilk while panel $C$ includes infants who were also fed other foods. The nearly parallel declines in the incidence and duration of breastfeeding

TABLE 2. TRENDS IN INFANT-FEEDING PRACTICES, BERLIN, 1885-1910.

\begin{tabular}{|c|c|c|c|c|c|c|}
\hline \multirow[b]{2}{*}{ Variable } & \multicolumn{6}{|c|}{ Year } \\
\hline & 1885 & 1890 & 1895 & 1900 & 1905 & 1910 \\
\hline \multicolumn{7}{|c|}{$\begin{array}{l}\text { A. Percentage of Infants Receiving Following } \\
\text { Types of Food at the Census }\end{array}$} \\
\hline Breast milk & 55.2 & 50.7 & 43.1 & 31.4 & 31.2 & 30.5 \\
\hline Wet nurses' milk & 2.7 & 2.2 & 1.4 & 0.7 & 0.6 & 0.4 \\
\hline Mixed & 6.7 & 4.8 & 9.9 & 14.4 & 4.2 & 3.7 \\
\hline Animal milk & 33.9 & 42.3 & 45.3 & 49.7 & 63.7 & 62.6 \\
\hline Unknown & 1.5 & 0.0 & 0.2 & 3.8 & 0.3 & 2.8 \\
\hline Total & 100.0 & 100.0 & 99.9 & 100.0 & 100.0 & 100.0 \\
\hline \multicolumn{7}{|l|}{ B. Fully Breastfed Infants } \\
\hline Median duration (in months) & 8.07 & 6.78 & 3.31 & 1.30 & 1.32 & 1.68 \\
\hline Percentage ever breastfedb & 78.5 & 78.6 & 71.5 & 63.9 & 62.1 & 70.2 \\
\hline \multicolumn{7}{|c|}{ C. Breastfed Infants and Those Fed Mixed Diet } \\
\hline Median duration (in months) ${ }^{a}$ & 8.58 & 7.35 & 4.58 & 2.21 & 1.94 & 2.11 \\
\hline Percentage ever breastfed $b$ & 78.9 & 79.5 & 72.31 & 67.3 & 65.6 & 71.8 \\
\hline
\end{tabular}

NoTEs: aEstimated as weighted average of 3 month moving averages where the weights are the number of infants in each monthly age group.

bEstimated by linear extrapolation using the percentage breastfed for the two closest age groups. 


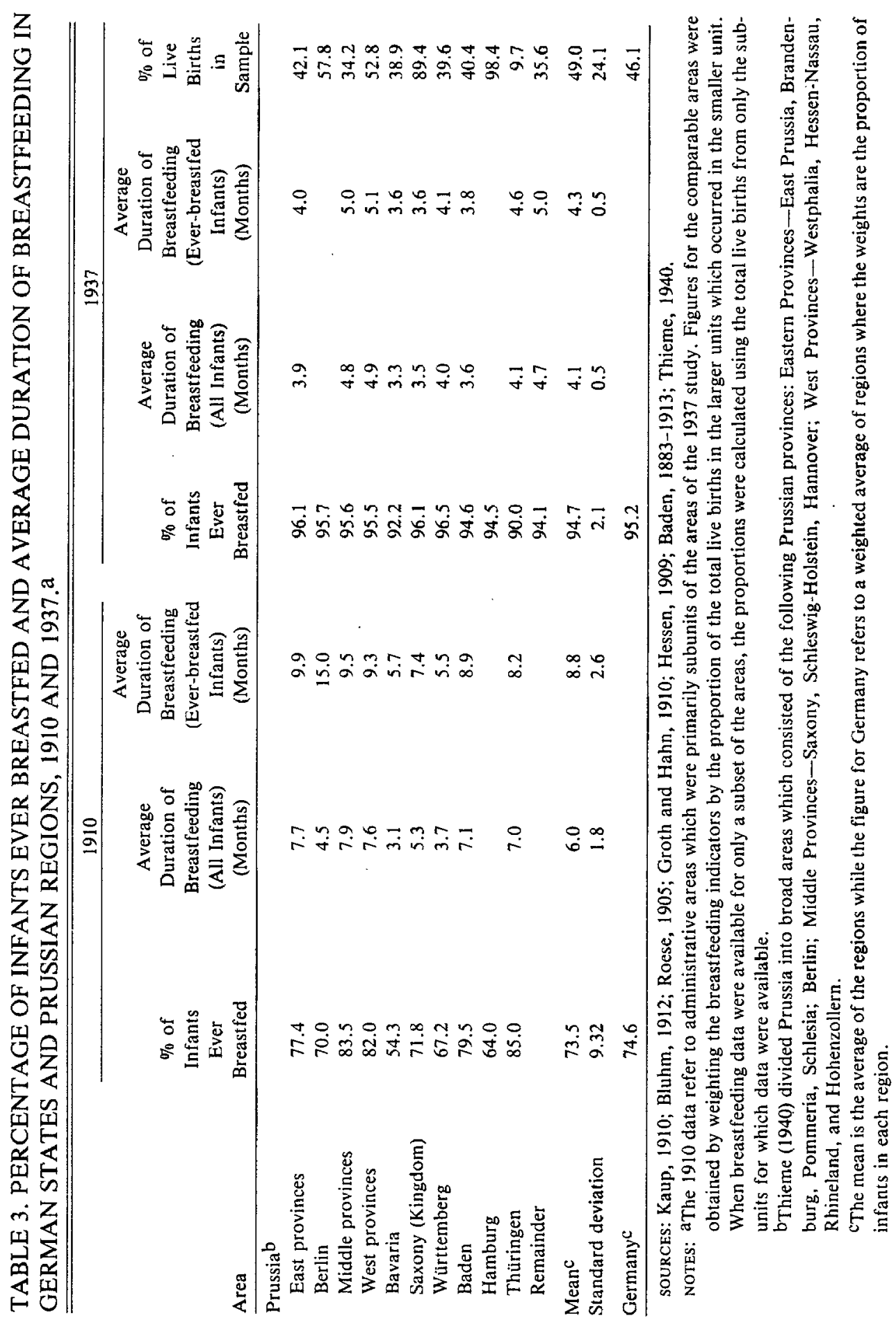


indicate that both the decision to breastfeed at all and the decision of how long to breastfeed were affected. Declines in both measures were pronounced: the percentage of infants ever breastfed (panel C) fell from 79 percent in 1890 to about 66 percent in 1905, while the median duration of breastfeeding fell from 8.5 months in 1885 to just under 2 months in 1905 .

\section{The Resurgence in Breastfeeding}

Although a few local studies reported large increases in the incidence of breastfeeding (Beck, 1924; Kretschmar, 1920; Kukowka, 1938), the extent of this unusual reversal is most evident in a comparison of data sets concerning regional differences in infant-feeding practices during 1910 and 1937.

Table 3 shows that for Germany as a whole in 1910 about 75 percent of infants received some breast milk, but, by 1937 , 95 percent of all infants were breastfed. These figures are the same whether the average is taken over regions or whether a weighted average is used, in which the weights are the proportion of total live births in that area. The incidence of breastfeeding rose to at least 90 percent in all areas, including cities such as Hamburg and Berlin (Guradze, 1928), where breastfeeding had declined earlier and in the southern areas formerly known for the custom of never breastfeeding. The extremely sharp regional differences in the percentage of infants ever breastfed had all but disappeared in 1937.

Despite the resurgence in the incidence of breastfeeding, the average duration of breastfeeding of all infants (including those who were never breastfed) fell sharply in all areas except Bavaria and Württemberg, two regions known for never breastfeeding. The latter result is surprising in view of the very high incidence of breastfeeding and indicates that the duration of breastfeeding among ever breastfed infants declined. Indeed, the average duration of breastfeeding of ever breastfed infants decreased across all areas, but most particularly in those areas of 1910 in which breastfeeding was most common and lasted longest.

Further evidence of this remarkable increase in breastfeeding in areas in which the custom of never breastfeeding was traditional is provided by time series data on breastfeeding in the state of Baden and in Munich. These data also shed light on the timing of the increase.

Figure 1 shows that the incidence of breastfeeding in Baden rose from 77.4 percent in 1873 to 97.3 percent in 1933 . However the rise was not continuous. Following an initial increase from 1875 to 1885 , the incidence of breastfeeding fell steadily until 1903. The increase of approximately 20 percent occurred in only 30 years, from 1903 to 1933 . This timing suggests that food shortages resulting from the First World War, the period of hyperinflation, and the infant welfare movement with its intensive campaign to promote breastfeeding may have been important contributors to this increase in breastfeeding.

FIGURE 1. THE PERCENTAGE OF INFANTS EVER BREASTFED, BADEN, 1873-1934.

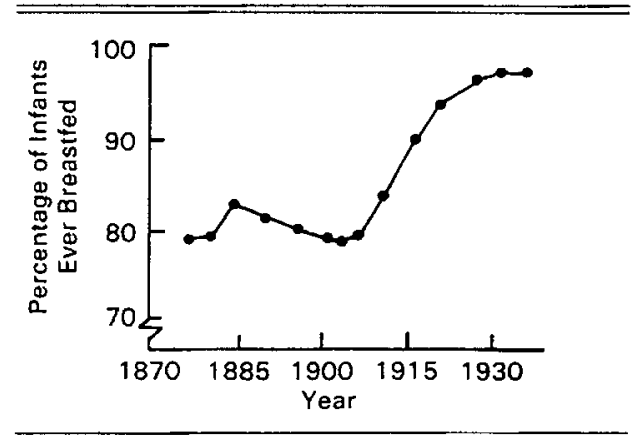

SOURCE: Günther, 1937. 
Munich also experienced a rapid reversal in breastfeeding. Figure 2 indicates that the percentage of infants ever breastfed rose from only 14 percent in 1877 to 91 percent in 1933. It fell slightly from $1861 / 1869$ to $1879 / 1886$ and then rose continuously, aside from a slight reversal between 1905 and 1910. As in Baden, the increase in the incidence of breastfeeding was particularly rapid during the period between the two world wars.

The trend in the average duration of breastfeeding is more complex. Figure 3 shows that although the average duration

FIGURE 2, THE PERCENTAGE OF INFANTS EVER BREASTFED, MUNICH, 1869-1933.

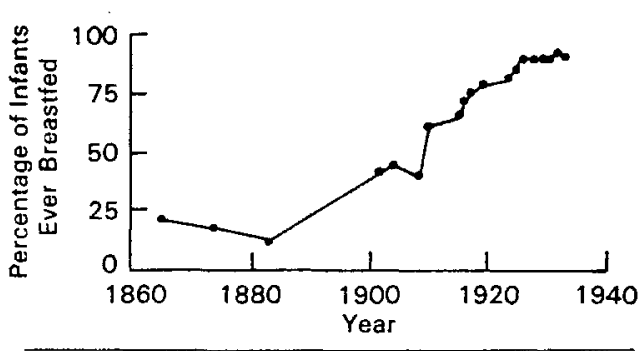

FIGURE 3. THE AVERAGE DURATION OF BREASTFEEDING, MUNICH, 1903-1933.

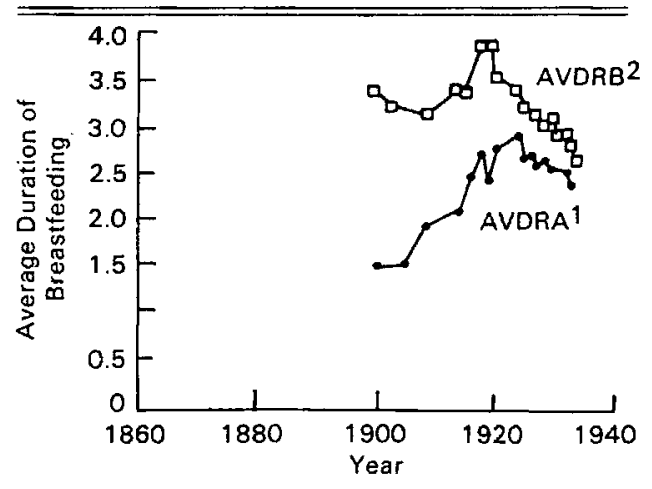

NOTES: 'Average duration of breastfeeding of all infants.

${ }^{2}$ Average duration of breastfeeding of only breastfed infants. of breastfeeding of all infants doubled between the turn of the century and 1924, it declined slightly thereafter. This trend reflects the movement in the average duration of breastfeeding of ever breastfed infants, which declined sharply after 1924 to only 75 percent of its level at the turn of the century. Despite the remarkable increase in the incidence of breastfeeding, the average duration of breastfeeding fell considerably.

Though a resurgence in the incidence of breastfeeding is consistently evident in the preceding data sets, it is nevertheless possible that this trend is misleading because the samples were not representative of the entire population. Upper-class mothers in particular were quite likely to have been excluded from the studies. A study of infant-feeding practices among families of pediatricians, obstetricians, and gynecologists suggests that the incidence of breastfeeding also rose dramatically in this segment of the population (Schlossmann et al., 1924), providing this sample can be considered representative.

\section{What Caused the Resurgence in the Incidence of Breastfeeding?}

This review of trends in infant-feeding practices shows that breastfeeding patterns changed considerably during the late nineteenth and early twentieth centuries. By 1937 the incidence of breastfeeding had risen in all areas, including those in which the custom of never breastfeeding was common. It also appears that breastfeeding became prevalent among all socioeconomic strata. The sharp regional differences in both the incidence and average duration of breastfeeding present in 1910 had disappeared by 1937. Time series data concerning Baden and Munich indicates that this increase in breastfeeding occurred mainly during the period between the two world wars. 
Accompanying the resurgence in the incidence of breastfeeding was a decline in the average duration of breastfeeding, as can be seen in both the 1910-1937 comparison and in Munich. This decline occurred in all areas, including those in which the custom of never breastfeeding was common. The sharp regional differences in the duration of breastfeeding present in 1910 were considerably reduced by 1937 . Time series data from Munich suggest that most of this decline occurred rapidly (from 1924 to 1937) and that it began during the period of hyperinflation.

The statistical information presented here indicates that the trend in breastfeeding during the early twentieth century was complex-the duration of breastfeeding fell while the incidence of breastfeeding rose. This pattern suggests that the increase in the incidence of breastfeeding did not mean that most of the population had returned to the former regime of prolonged breastfeeding but rather that most infants were breastfed for only three to four months.

Several factors may have contributed to the resurgence in breastfeeding. Food shortages stemming from the blockades in World War I and from postwar economic conditions probably led many mothers to abandon expensive and hard to find artificial foods. A similar situation may have occurred in Paris in 1870-1871, when a food blockade was associated with a drop in infant mortality because of an increase in breastfeeding (Morse and Talbot, 1920, cited in Wray, 1979). Changes in female labor force participation were probably not responsible for the increased incidence of breastfeeding. However, it may partly account for the reduction in the duration of breastfeeding. The increase in breastfeeding occurred during a time when the labor force participation of women increased (Knodel, 1974).

It is not possible to examine the influence of various social and economic factors on the trend in breastfeeding for several reasons. No data are available for the 1910-1937 comparison or for Baden. Furthermore, the time series for the trend in Munich is too short for multivariate analysis.

The remainder of this paper focuses on government policies and voluntary efforts to promote breastfeeding. The campaign to increase breastfeeding consisted of several measures, including infant welfare centers and allowances to mothers.

\section{Infant Welfare Centers}

The infant welfare movement created several institutions that directly affected infant health. Infant hospitals, orphanages, and infant homes began to be established and lying-in hospitals became more frequent in the early nineteenth century, while the construction of nurseries, infant welfare centers, and milk kitchens began in the mid- to late nineteenth century (Keller, 1912). The movement consisted of loosely associated private local charities until 1934. It succeeded in instituting several legislative reforms, including the establishment of publicly funded infant welfare centers, and in establishing governmental programs designed to facilitate and encourage breastfeeding (Keller, 1912; Thieme, 1940).

The infant welfare movement stemmed in part from widespread awareness of Germany's high infant mortality rates relative to other European countries (Kintner, 1982). Advocates of infant welfare focused on the advantages of maternal breastfeeding after epidemiological and clinical studies demonstrated the disadvantages of artificial feeding. Boeckh's (1885) study of infant mortality 
rates by feeding method was very influential. It showed that mortality rates of bottle-fed infants were seven times those of maternally breastfed infants.

Infant welfare centers promoted breastfeeding in several ways. They held classes in infant care and nutrition, including breastfeeding techniques, and evaluated familial child care through regular medical examinations and home visits (Wuertz, 1912). They distributed animal milk to nursing mothers to supplement their diets and gave sterilized milk for the infants of mothers who could not breastfeed their infants (Szyszka, 1920). Infant welfare centers were the center of an educational campaign to encourage breastfeeding (Keller, 1912; Wuertz, 1912). They may also have indirectly affected infant-feeding practices by publicizing breastfeeding and other effective child care practices to those who did not actually utilize their services.

The direct effectiveness of infant welfare centers depended upon the percentage of live births observed by the centers and the regularity of their visits. It is difficult to get an impression of how much infant welfare centers were utilized because few statistics were published. Also, it is doubtful that published statistics apply equally to all centers because there were great local differences in the frequency of visits (Wuertz, 1912). Infant welfare centers were most effective when mothers were able to return periodically to permit further examination of their infants and when necessary to receive instructions in child care methods. Before the 1934 unification of all infant welfare centers, a local program was considered successful if 60-80 percent of infants living around a center were contacted (Hellbruegge and Pechstein, 1966). It is likely that fewer infants visited the centers in the early 1900 s, when they were just starting. In 1909, for instance, only about 5 per- cent of the infants in Munich visited a center (Wuertz, 1912). A higher proportion of infants were seen, however, when the infant welfare centers became well known. By 1934,89 percent of the infants in Berlin, 78 percent of those in large cities, 80 percent of those in other urban areas, and 62 percent of the infants in rural areas were observed by infant welfare workers (Teleky, 1950). Information on how long these infants continued to be seen by the centers is unavailable.

There is some evidence that infant welfare centers directly influenced the incidence and duration of breastfeeding. Hecker (1920) found that two-thirds (66.3 percent) of the children seen by the infant welfare center were breastfed, while only about one-fifth ( 23.5 percent) who were not seen by the center but whose mothers received allowances were breastfed. This finding was not due to differences in the rates of illegitimate births of the two samples. Also, the average duration of breastfeeding was slightly longer for those seen by the infant welfare center than for the other group.

\section{Mother and Nursing Allowances}

The other chief policies to increase breastfeeding involved legal protection of mothers in the paid labor force and nursing allowances. Much of the following discussion is taken from Thieme (1940).

Legal protection of working mothers began with the Mother Protection Law of 1878, which prohibited mothers from working in the first three weeks after delivery. Because it frequently resulted in the mothers losing their jobs, the law was changed in 1887 so that mothers were paid during this period (Wochenhilfe). This payment was designed to give mothers the opportunity to nurse. They could maintain a diet adequate for nursing and also replace the money they would have earned had they been working. In 1927 mothers 
gained the right to stop working six weeks before delivery until six weeks after delivery without risk of being fired. They also had the right to nursing breaks after resuming their work.

Nursing allowances (payments for breastfeeding), which originated in France in 1892, were introduced into Germany in Munich in 1904. Many other German cities quickly adopted them. By 1907,77 cities offered some form of nursing allowance or premium (Keller, 1909). Insurance companies took up the nursing allowances in 1911. Legal regulation of the mother and nursing allowances began in 1914, when they were guaranteed to the wives of World War I veterans. A twelveweek nursing allowance available to all was established in 1919.

Nursing allowances had several purposes. They were a means to improve the nutritional level of the mother to facilitate her own milk production (Heilmaier, 1916). They could also be used to require women to make periodic visits to infant welfare centers for medical examinations of infants. Many communities made use of this possibility by giving infant welfare centers authority over nursing allowances (Plaschke, 1928). The allowances were also thought to provide good preparation for breastfeeding subsequent children (Heilmaier, 1916).

The form of the nursing allowance varied locally and over time. In 190770 percent of the 77 cities with such programs offered monetary allowances while 13 percent offered it in terms of free milk, which was intended to raise mothers' nutritional level. The remaining 17 percent of the cities provided other items or services, such as food packages and laundry (Keller, 1909).

The monetary allowances were generally quite small. In 1907 cities paid an average of 2.35 Marks per week for a period usually less than or equal to twelve weeks (Keller, 1909). This payment was quite small compared to an average weekly wage for women of about 12 Marks. $^{3}$ Nursing allowances remained quite small even after their assumption by insurance companies. The median daily allowance in 1926 was .41-.5 Marks (Plaschke, 1928), which was trivial compared to the average daily wage for women of 3.5 Marks. ${ }^{4}$

The effect of nursing allowances was rarely evaluated, which is surprising in light of how well established they were. They were generally considered quite effective because it was thought that most mothers stopped breastfeeding after the allowances ended in the twelfth week after birth. A more formal method of evaluating their effectiveness compared how mothers fed children born before and after nursing allowances were introduced. These studies report slight increases in the incidence of breastfeeding, ranging from 3.9-7.1 percent in Karlsruhe, Baden in 1907-1908 (Schiller, 1909) to 9 percent in Berlin (Neumann, 1908). None of these studies provide the information needed to examine the statistical significance of these increases.

Another study examined the effect of nursing premiums which supported nursing beyond the legally mandated twelve weeks. Kessler (1939) found that the

${ }^{3}$ The daily wage for women in 1907 was estimated as 44 percent of the men's wage at that time. This figure is the sex differential in wages in 1914 but it remained fairly constant between 1907 and 1914 (Bry, 1960). The men's wage for 1907 was obtained by adjusting the 1914 men's wage by a wage index (Bry, 1960:329). Weekly wages were obtained by multiplying the daily wage by six, the average number of days worked per week.

'Weekly wages for women in 1926 were estimated as 44 percent of the 1926 wage for men. The weekly wage was divided by six to get the daily wage. Wage information was obtained from Bry, 1960. 
average duration of breastfeeding of those receiving premiums in the form of food packages was two and a half months longer than for mothers not receiving such packages. He also found that the influence of premiums fell off after eight months. The effect of the premiums may be underestimated, however, because breastfed infants who left observation before weaning were excluded from the analysis. Since infants of mothers receiving packages were more likely to be breastfed for a longer time, they were more likely to be excluded from the calculations.

The preceding studies indicate that nursing allowances increased the incidence of breastfeeding only slightly. They may however have had a greater impact on the duration of breastfeeding. By 1937 most infants were breastfed for only a month beyond the twelve-week nursing allowance. The Kessler (1939) study indicates that allowances could influence the duration of breastfeeding. It suggests that the duration of breastfeeding would have increased had nursing allowances been extended beyond the legal requirement. Such premiums were, however, comparatively rare (Plaschke, 1928).

Several reasons were suggested why nursing allowances had minimal effects. Payment of allowances or premiums was not well known among certain segments of the population, such as poor women and mothers of illegitimate children (Neumann, 1908; Heilmaier, 1916). Payments were frequently made considerably after the behavior they were designed to reward (Neumann, 1908). Allowances were sometimes restricted to the most needy (Plaschke, 1928) and may have bypassed more well-off groups in which the incidence of breastfeeding was lower.

\section{Summary and Discussion}

This paper has described breastfeeding patterns in Germany from 1871 to 1937. As in most of Europe, breastfeeding was common in Germany around 1910. At that time an average of nearly threequarters of the infants in an administrative area (a province or duchy) received some breastmilk during the period 1903-1909. The average duration of breastfeeding was around six months. There were sharp regional differences in the incidence and duration of breastfeeding. Prolonged breastfeeding was common throughout northwestern Germany, aside from major cities such as Berlin, Hamburg, and Bremen. In contrast, most infants were never breastfed in southeastern Germany.

Trends in infant-feeding practices during the late nineteenth and early twentieth centuries were discussed in the second section of the paper. The erosion of breastfeeding in major urban areas during the late nineteenth century was examined in Berlin during 1885-1910. Declines in both the incidence and duration of breastfeeding were pronounced. The proportionate decline in the median duration of breastfeeding was much greater than that in the incidence of breastfeeding. The popularity of animal milk rose with the fall in breastfeeding.

Trends in breastfeeding in the early twentieth century for Germany as a whole were examined by comparing regional breastfeeding patterns in 1937 to those around 1910 . The incidence of breastfeeding rose and the duration of breastfeeding fell between 1910 and 1937. By 193795 percent of all infants were breastfed, an increase of 20 percent from 1910 . The incidence of breastfeeding rose to at least 90 percent in all areas, including cities which had experienced earlier erosions in breastfeeding and in the southern areas formerly known for the custom of never breastfeeding. The average duration of breastfeeding fell sharply in all areas except two 
regions known for never breastfeeding. The formerly sharp regional differences in the incidence and duration of breastfeeding apparent around 1910 had disappeared by 1937 . Instead, nearly all infants were breastfed for only three to four months. Time series data from Baden and Munich suggest that the increase in the incidence of breastfeeding was particularly rapid after the first World War. The data also document the divergent trends in the incidence and duration of breastfeeding.

The trend in breastfeeding described in this paper is unusual in two respects. First, it is a resurgence in the incidence of breastfeeding. Documented increases in breastfeeding, such as occurred among contemporary college-educated women in the United States (Hendershot, 1980), are rare. Second, the resurgence in the incidence of breastfeeding was accompanied by a reduction in the duration of breastfeeding. Most studies have found that the incidence and duration of breastfeeding change in the same manner. A recent literature review found that among countries for which enough information was available to examine changes over time, trends in the incidence of breastfeeding mirrored those in the duration of breastfeeding (Millman, 1982). These countries include Panama, South Korea, Taiwan, and Malaysia. Results are inconclusive in Thailand, where a decline in the duration was accompanied by near stability in the incidence of breastfeeding. Trends in the incidence and duration of breastfeeding also followed the same direction in Europe from 1930 to 1960 (Vahlquist, 1975).

The unusual nature of the German trend in infant-feeding practices indicates that further research should be done on trends in other European countries to see if the German trend is representative. It also suggests some caution in viewing the trend. Although all available evidence supports it, the possibility that the German trend reflects differences in the composition of the samples cannot be overlooked.

This paper also discussed the influence of several social, economic, and cultural factors on breastfeeding. Regional breastfeeding patterns were correlated with geographical variation in female labor force participation and illegitimacy. Local breastfeeding customs probably also influenced the incidence and duration of breastfeeding but it was not possible to correlate these measures. Regional breastfeeding patterns were unrelated to milk price probably because few substitute infant foods contained milk.

The timing of the trends in the early twentieth century suggests that food shortages resulting from the first World War, the period of hyperinflation, and efforts to promote breastfeeding may have been important contributors to this increase in the incidence of breastfeeding.

The campaign to increase breastfeeding consisted of several measures, including infant welfare centers and allowances to mothers. Infant welfare centers held classes in infant care and nutrition, provided regular medical examinations, and distributed milk to supplement the diet of nursing mothers. There is some evidence that infant welfare centers directly increased the incidence and duration of breastfeeding. Less information is available, however, on the percentage of infants seen by these centers. While at least 60 percent were seen by them in 1934, far fewer visited them prior to this time. No time series data are available which might further pinpoint when a sizable proportion of infants began to visit the infant welfare centers.

The other chief policy to promote breastfeeding involved legal protection of mothers in the paid labor force and nursing allowances. From 1878 to 1927 a series 
of laws were enacted which resulted in the granting of a twelve-week paid maternity leave. Nursing allowances (payments for breastfeeding) were introduced in Germany in 1904. They quickly became popular and by 1919 a 12-week long nursing allowance was available to all. These allowances, which were usually monetary, were considered effective although they were small compared to women's wages and despite few formal evaluations. They resulted in slight increases in the incidence of breastfeeding. They may have encouraged breastfeeding for only the threemonth duration of the allowances. However, their effectiveness was diminished by lack of publicity, late rewards, and restrictions to certain population groups.

Further research is needed to document infant-feeding practices in other historical populations to see whether trends noted here are representative of conditions elsewhere. More research on the political and educational campaigns designed to promote breastfeeding and protect working mothers would provide additional insight into the factors influencing decisions about infant-feeding practices.

\section{BIBLIOGRAPHY}

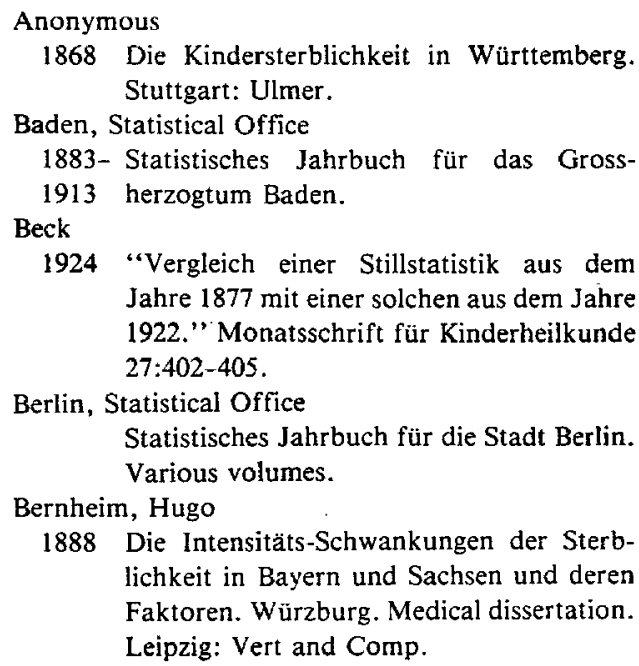

1868 Die Kindersterblichkeit in Württemberg Stuttgart: Ulmer.

Baden, Statistical Office

1883- Statistisches Jahrbuch für das Gross-

1913 herzogtum Baden.

Beck

1924 "Vergleich einer Stillstatistik aus dem Jahre 1877 mit einer solchen aus dem Jahre 1922." Monatsschrift für Kinderheilkunde $27: 402-405$

Berlin, Statistical Office

Statistisches Jahrbuch für die Stadt Berlin. Various volumes.

Bernheim, Hugo

1888 Die Intensitäts-Schwankungen der Sterblichkeit in Bayern und Sachsen und deren Faktoren. Würzburg. Medical dissertation. Leipzig: Vert and Comp.

Biedert, $\mathrm{Ph}$.

1905 Die Kinderernährung im Säuglingsalter und die Pflege von Mutter und Kind. 5 ed. Stuttgart: F. Enke.

Bluhm, Agnes

1912a "Stillfähigkeit." In A. Grotjahn and J. Kaup, eds., Handwörterbuch der Sozialen Hygiene, vol. 2, 555-570. Leipzig: Vogel.

1912b "Stillhäufigkeit und Stilldauer." In A. Grotjahn and J. Kaup, eds., Hand. wörterbuch der Sozialen Hygiene, vol. 2, 570-591. Leipzig: Vogel.

Boeckh

1885 "Die Sterblichkeit des Kindes nach der Ernährungsweise." Statistisches Jahrbuch der Stadt Berlin, 13.

Bongaarts, John and R. Potter

1983 Fertility, Biology and Behavior: An Analysis of the Proximate Determinants. New York: Academic Press.

Bruening, $\mathrm{H}$.

1908 Geschichte der Methodik der künstlichen Säuglingsernährung. Stuttgart: Enke.

Bry, G.

1960 Wages in Germany, 1871-1945. Princeton: Princeton University Press.

Chandra, R. K.

1978 "Immunological Aspects of Human Milk." Nutrition Review 36:265-272.

Cunningham, Alan S.

1981 "Breastfeeding and Morbidity in Industrialized Countries: An Update." In E. Jelliffe and P. Jelliffe, eds., Advances in International Maternal and Child Health, vol. 1, 128-168. Oxford: Oxford University Press.

Escherich, T

1887 "Die Ursachen und Folgen des Nichtstillens bei der Bevölkerung Münchens." Münchener Medizinischer Wochenschrift $34: 1-3,256-259$.

Fischer, Alfons

1933 Geschichte des Deutschen Gesundheitswesens. vol. 2. Berlin: Kommissionsverlag F. A. Herbig.

Germany, Reichministerium des Innern

1937 Der öfentliche Gesundheitsdienst im Deutschen Reiche 1937. Veroffentlichungen aus dem Gebiete des Volksgesundheitsdienstes, vol. 53 , no. 2 .

Groth, A. and M. Hahn

1910 "Säuglingsverhältnisse in Bayern," Zeitschrift des Bayerischen Statistischen Landesamtes 42:78-164.

Günther, Walther

1937 "70 Jahre geburtshilfliche Statistik in 
Baden." Beiheft zum Reichsgesundheitsblatt $3: 17-42$.

Guradze

1928 "Über den Umfang der Brustmilchernährung bei Berliner Säuglingen." Archiv für Sozial Hygiene und Demographie, Neue Folge, 3, vol. 173:292-293.

Hecker, R.

1920 "Über den Einfluss organisierter Grossstadtfürsorge auf Ernährung, Mortalität, und Morbidität der Säuglinge." In F. Rott, ed., Beiträge zur Sozialen Hygiene des Săuglings- und Kleinkinderalters, 100-112. Berlin: G. Stolke.

1923 "Studien über Sterblichkeit, Todesursachen, und Ernährung Münchener Säuglinge." Archiv für Hygiene, vol. 93: 280-294.

Heilmajer, $O$

1916 "Über Säuglingshygiene." Öffentliche Gesundheitspflege mit besonderer Berücksichtigung der kommunalen und sozialen Hygiene. no. 1, 2:30-52, 83-105.

Hellbruegge, T. and J. Pechstein

1966 "Săuglingsfürsorge und Säuglingsschutz." In H. Opitz and F. Schmid, eds., Handbuch der Kinderheilkunde, vol. 3: 351-367. Berlin: Springer.

Hendershot, G.

1980 "Trends in Breastfeeding." National Center for Health Statistics, Advance Data, no. 59.

Hesse, Statistical Office

1909 Statistisches Handbuch für das Grossherzogtum Hessen. vol. 2.

Jain, A. K. and J. Bongaarts

1981 "Breastfeeding: Patterns, Correlates, and Fertility Effects." Studies in Family Planning 12:79-99.

Kaup, J.

1910 Ernährung und Lebenskraft der ländlichen Bevölkerung. Tatsachen und Vorschläge. Schriften der Zentralstelle für Volkswohlfahrt, neue Folge, no. 6.

Keller, Arthur

1909 "Der Umfang der Unterstützungen an stillende Mütter." Zeitschrift für Säuglingsschutz, vol. 1:180-185.

1912 "Sozial-Hygienischen Einrichtungen: Deutschland." In A. Keller and C. J. Klunker, Säuglingsfürsorge und Kleinkinderschutz in den europäischen Staaten. Berlin: Springer.

Kessler, F

1939 Stillprämien und ihr Einfluss auf die Mittlere Stilldauer. Medical dissertation, Breslau.
Kintner, Hallie $J$.

1982 The Determinants of Infant Mortality in Germany from 1871 to 1933 . Ph.D. dissertation, University of Michigan.

Knodel, John

1974 The Decline of Fertility in Germany, 1871-1939. Princeton: Princeton University Press.

1977 "Breastfeeding and Population Growth." Science 198:1111-1115.

Knodel, John and N. Debavalya

1980 "Breastfeeding in Thailand: Trends and Differentials, 1969-1979." Studies in Family Planning 11:355-377.

Knodel, John and E. van de Walle

1967 "Breastfeeding, Fertility and Infant Mortality: An Analysis of Some Early German Data." Population Studies 21:109-131.

Kretschmar, Richard

1920 "Die Ennährungsverhältnisse der Erstimpflinge in Jena, nach Erhebungen an den offentlichen Impfterminen im Juni 1919." In F. Rott, ed., Beiträge zur Sozialen Hygiene des Säuglings- und Kleinkinderalters, 113-145. Berlin: Stolke.

Kukowka

1938 Ein Bejtrag zur Stillfrage unter spezialler Berücksichtigung der Stillschwierigkeiten in der 2.13. und 6.17. Stillwoche und des Einflusses des Stillgeldes auf Stillfähigkeit und Stilldauer. Medical dissertation, Breslau.

Metlinger, B.

1473 Ein Regiment der jungen Kinder. Augsburg. Cited in Bruening, 1908.

Meyer, H. F.

1968 "Breastfeeding in the United States." Clinical Pediatrics 7:708-715.

Millman, Sara

1982 Breastfeeding in Taiwan: A Study of Change. Ph.D. dissertation, University of Michigan.

Morgenroth

1913 "Säuglingsernährung und Säuglingssterblichkeit in München." Mitteilungen des Statistischen Amtes der Stadt München 24:41-60.

Morse, J. L. and F. B. Talbot

1920 Diseases of Nutrition and Infant Feeding. $2 d$ ed. New York: MacMillan.

Mueller, F. W.

1912 Über die Ursachen des Nichtstillens auf der schwäbisch-bayerische Hochebene nebst geschichtlichen Notizen über das Nichtstillen überhaupt. Medical dissertation, Munich. 
Neumann, $\mathrm{H}$

1908 "De Unterstützung der stillenden Mü und ihr Erfolg." Ergebnisse der Säugii fürsorge 5:51-58.

Peiper, A.

1966 Chronik der Kinderheilkunde. 4th Leipzig: Georg Thieme.

Plaschke, U.

1928 “Über Stillbeihilfen." Gesundheitsfürsorge für das Kindesalter 3:267-285.

Pohlen, Kurt

1937 "Die Statistik der Stillhäufigkeit und Stilldauer in der Säuglingsfürsorge. Mit Richtlinien zur Ausfüllung der Fragen über die Stillfrequenz in den deutschen Jahresgesundheitsberichten." Der Öffentliche Gesundheitsdienst 3 Part B, no. 1:42-48.

1939 "Die Stillfrequenz und Stilldauer in der deutschen Säuglingsfürsorge." Der Öffentliche Gesundheitsdienst 4, no. 19:537-549.

Prinzing, $\mathrm{F}$.

1906 Handbuch der Medizinischen Statistik. Jena: Fischer.

Roese, C.

1905 "Die Wichtigkeit der Mutterbrust für die körperliche und geistige Entwicklung des Menschen." Deutsche Monatsschrift für Zahnkunde 23, no. 3:129-176.

Rollet, Catherine

1978 "Allaitment, mise en nourrice et mortalité infantile en France à la fin du XIXe siécle." Population 33:1 189-1203.

Schiller, R.

1909 "Stillprämien und Stillbeihilfen im Kampfe gegen die Säuglingssterblichkeit." Zeitschrift für Säuglingsfürsorge 3 : 321-333.

Schlossmann, A., O. Pankow, and E. Schlossmann 1924 "Über die Zunahme des Stillwillens." Klinische Wochenschrift 3, no. 2:79-81.

Seidlmayer, Hubert

1937 Geburtenzahl, Säuglingssterblichkeit und Stillung in München in den letzten 50 Jahren. Ph.D. dissertation, Ludwig-Maxmillians-Universität. Munich: L. Moessl.

Seutemann, Karl

1913 "'Säuglingsnährung und Säuglingssterblichkeit nach Ernährungsweise in der Stadt Hannover," in Kommittee zur Ermittlung der Säuglingsnährung in Hannover-Linden, Säuglingsnährung, Säuglingssterblichkeit und Säuglingsschutz in den Städten Hannover und Linden. Berlin, 34-97.

Spree, Reinhard

1978 "Die Entwicklung der differentiellen Säuglingssterblichkeit in Deutschland seit der Mitte des 19. Jahrhunderts." Paper presented at the International Colloquium on Man and Health in History, Berlin, Freie Universität, Department of History, under the direction of A. Imhof.

Sussman, George

1977 "The End of the Wet-Nursing Business in France, 1874-1914." Journal of Family History 2:237-258.

Szyszka, W.

1920 "Die Säuglingssterblichkeit der Stadt Würzburg in den Kriegsjahren und der Einfluss der Säuglingsfürsorge." In F. Rott, ed., Beiträge zur Sozialen Hygiene des Säuglings- und Kleinkinderalters, 82-99. Berlin: G. Stolke.

Teleky, $L$.

1950 Die Entwicklung der Gesundheitsfürsorge: Deutschland, England, USA. Berlin: Springer.

Teuteberg, Hans Jürgen and A. Bernhard

1978 "Wandel der Kindernährung in der Zeit der Industrialiserung." In J. Reulecke and W. Weber, eds., Fabrik-FamilieFeierabend. Beiträge zur Sozialgeschichte des Alltags im Industriezeitalter. 2 ed. Wuppertal.

Thieme, $\mathbf{J}$.

1940 "Stillhäufigkeit und Stilldauer in den einzelnen Reichsteilen im Jahre 1937." Reichsgesundheitsblatt 15:909-918, 937-945.

Thomson, A. M., F. Hytten, and A. Black

1975 "Lactation and Reproduction." Bulletin, World Health Organization 52:337-349.

Tyson, J. E. and A. Perez

1978 "The Maintenance of Infecundity in Postpartum Women." In W. H. Mosley, ed., Nutrition and Human Reproduction. New York: Plenum Press.

Vahlquist, Bo

1975 "Evolution of Breastfeeding in Europe." Environmental Child Health v. 21:11-18.

van Ginneken, J.

1974 "Prolonged Breastfeeding as a Birth Spacing Method." Studies in Family Planning 5:201-206.

Woodbury, R. M

1925 Causal Factors in Infant Mortality. United States Department of Labor, Children's Bureau Publication, no. 142.

Wray, Joe D.

1978 "Maternal Nutrition, Breastfeeding and Infant Survival." In W. H. Mosley, ed. Maternal Nutrition and Reproduction, 197-230. New York: Plenum Press.

1979 "Feeding and Survival: Historical and Contemporary Studies of Infant Morbidity and Mortality." Unpublished paper. 
Wuertz, A.

1912 "Säuglingsfürsorge." In A. Grotjahn and J. Kaup, eds., Handwörterbuch der Sozialen Hygiene 2, 229-271. Leipzig: Vogel. 